PEREIRA, Diego Emmanoel Serafim. O dever de participação na proteção em matéria ambiental na legislação brasileira. Revista Eletrônica Direito e Política, Programa de Pós-Graduação Stricto Sensu em Ciência Jurídica da UNIVALI, Itajaí, v.10, n.1, edição especial de 2015. Disponível em: www.univali.br/direitoepolitica - ISSN 1980-7791.

\title{
O DEVER DE PARTICIPAÇÃo NA PROTEÇÃo EM MATÉRIA AMBIENTAL NA LEGISLAÇÃO BRASILEIRA
}

\author{
EL DEBER DE PARTICIPACION EN LA PROTECION EN MATERIA AMBIENTAL \\ EN LA LEGISLACIÓN BRASILEÑA
}

\section{Diego Emmanoel Serafim Pereira ${ }^{1}$}

SUMÁRIO: Introdução; 1. A transformação do Estado diante do risco ambiental; 2. O dever de participação do cidadão na proteção ambiental; 3. O dever de participação na legislação brasileira em matéria ambiental; Considerações finais; Referências das fontes citadas.

RESUMO: Este artigo analisa a participação dos cidadãos na proteção do meio ambiente na legislação brasileira. A participação popular não é vista apenas como um direito, mas como um dever ético em razão dos riscos ambientais contemporâneos. O Estado atual deve estimular a solidariedade e a cooperação dos indivíduos na preservação do meio ambiente, promovendo a educação ambiental e elaborando leis que permitam o exercício da cidadania ambiental desde a tomada de decisões até as atividades concretas de proteção aos recursos naturais.

Palavras-Chaves: Dever de participação; Ética ambiental; Estado Ambiental.

RESUMEN: En este artículo se analiza la participación de los ciudadanos en la protección del medio ambiente en la legislación ambiental brasileña. La participación popular no es visto sólo como un derecho sino como un deber ético sobre la base de los riesgos ambientales contemporáneos. El estado actual se debe promover la solidaridad y la cooperación de los individuos en la conservación del medio ambiente a través de la promoción de la educación ambiental y la elaboración de leyes que permiten la práctica de la ciudadanía ambiental a partir de la toma de decisiones a las actividades específicas para la protección de los recursos naturales.

Palabras clave: Deber de participar; Ética del Medio Ambiente, Estado del Medio Ambiente.

\footnotetext{
${ }^{1}$ Mestrando em Ciências Jurídicas pela Universidade do Vale do Itajaí - UNIVALI, Linha de Pesquisa Direito Ambiental, Transnacionalidade e Sustentabilidade. Graduado em Direito pelo Centro Universitário de Brusque - UNIFEBE e pós-graduado em Direito Público pela Universidade Regional de Blumenau Advogado. E-mail: diego1801@terra.com.br
} 
PEREIRA, Diego Emmanoel Serafim. O dever de participação na proteção em matéria ambiental na legislação brasileira. Revista Eletrônica Direito e Política, Programa de Pós-Graduação Stricto Sensu em Ciência Jurídica da UNIVALI, Itajaí, v.10, n.1, edição especial de 2015. Disponível em: www.univali.br/direitoepolitica - ISSN 1980-7791.

\section{INTRODUÇÃO}

A crise ambiental que ocorre no planeta demonstra que o modelo de proteção do meio ambiente não é satisfatório. A mudança de paradigma envolve a mudança de inúmeros hábitos e comportamentos como nas relações de consumos, relações sociais e políticas. O envolvimento do cidadão com as questões ambientais não pode mais ser visto apenas como um direito, mas como um dever ético voltado à proteção da vida e do planeta.

A solidariedade é vista como um princípio e a cooperação para com os demais cidadãos e com o Estado é uma exigência para que se possa garantir o desenvolvimento sustentável da sociedade. Exige-se uma participação maior de todos na preservação do meio ambiente, envolvendo aspectos que vão desde o acesso à informação até a elaboração de políticas públicas ambientais, em busca de um desenvolvimento que possa garantir o gozo dos recursos naturais às gerações presentes e futuras.

Inúmeros tratados internacionais e Constituições de diversos países já estabelecem que o meio ambiente ecologicamente equilibrado não é apenas um direito aos cidadãos, mas que compete também a estes o dever de proteger o planeta através da gestão compartilhada entre Estado e Sociedade. O Estado brasileiro possui uma legislação com inúmeros instrumentos que buscam permitir a participação democrática na preservação dos recursos ambientais, bem como conscientizar a sociedade das ameaças ambientais.

O objetivo deste artigo é analisar como a legislação brasileira permite a participação popular que não é tida apenas como um direito, mas como um dever do cidadão frente às questões ambientais que envolvem o Estado e o desenvolvimento sustentável da sociedade. A metodologia utilizada para o desenvolvimento deste artigo é o método indutivo valendo-se da pesquisa bibliográfica como apoio à investigação.

\section{A TRANSFORMAÇÃO DO ESTADO DIANTE DO RISCO AMBIENTAL}


PEREIRA, Diego Emmanoel Serafim. O dever de participação na proteção em matéria ambiental na legislação brasileira. Revista Eletrônica Direito e Política, Programa de Pós-Graduação Stricto Sensu em Ciência Jurídica da UNIVALI, Itajaí, v.10, n.1, edição especial de 2015. Disponível em: www.univali.br/direitoepolitica - ISSN 1980-7791.

É pacifico o entendimento que a preservação do meio ambiente é questão de vida ou morte, pois os riscos de um colapso ambiental são perceptíveis. A extinção de espécies animais e vegetais, a desertificação, contaminação de solo, mudanças climáticas são manifestações que mostram o quanto é perigoso não tomar os devidos cuidados na proteção do meio ambiente equilibrado.

O aumento dos desastres ambientais, como as enchentes e secas prolongadas relacionadas com o aquecimento global e a emissão de gases provocam, danos incalculáveis e milhões de vítimas em todo o mundo. O aumento do número de refugiados ambientais e dos danos causados pelas catástrofes não podem ser tratados apenas como uma crise ambiental, mas também de uma crise com dimensão social, econômica, política e cultural.

Assim, como uma guerra nuclear, a crise ambiental atual pode inviabilizar a continuidade da vida humana na Terra. Os séculos de devastação e a ausência de políticas públicas voltadas ao meio ambiente fez com que o Estado se tornasse cúmplice da atual situação vivida. Por essa razão, o Estado deve evoluir a partir da preocupação com as questões ambientais.

O Estado Democrático de Direito, nos moldes atuais, já não é mais suficiente para atender os anseios da sociedade. É necessário um novo modelo de Estado que tem como fundamento a defesa do meio ambiente adequado. Leite e Ayala ${ }^{2}$ apontam que o Estado de hoje, ainda, atua de forma conservadora, precária, insuficiente e predatória, sendo um Estado que permite a degradação ambiental dando preferência à gestão econômica e negligenciando o exercício da responsabilidade na preservação ambiental.

Ao se observar a evolução histórica do Estado percebe-se que no Estado Liberal não competia ao Estado intervir diretamente na sociedade, se limitando a prever e estabelecer alguns direitos. O Estado Liberal tinha como pressuposto permitir o máximo de bem-estar comum com a menor presença possível do Estado. O

\footnotetext{
${ }^{2}$ LEITE, José Rubens Morato; AYALA, Patryck de Araújo. Direito ambiental na sociedade de risco. Rio de Janeiro: Forense, 2002, p.321.
} 
PEREIRA, Diego Emmanoel Serafim. O dever de participação na proteção em matéria ambiental na legislação brasileira. Revista Eletrônica Direito e Política, Programa de Pós-Graduação Stricto Sensu em Ciência Jurídica da UNIVALI, Itajaí, v.10, n.1, edição especial de 2015. Disponível em: www.univali.br/direitoepolitica - ISSN 1980-7791.

Estado não intervinha em questões econômicas e sociais, tampouco ambientais. O Estado assumia uma postura neutra e omissa ${ }^{3}$.

A ausência do Estado em questões fundamentais criou uma série de injustiças sociais que culminam na transformação do Estado Liberal em Estado Social que pretendia realizar Justiça Social e uma melhor distribuição da riqueza. Ocorre que o Estado Social foi também um modelo de Estado que prioriza o indivíduo e não o coletivo. A busca por Justiça Social e distribuição da riqueza fez com que o Estado passasse a garantir o bem-estar individual, aumentando a qualidade de vida das pessoas, o que, por sua vez, aumentou o consumo e a utilização de recursos naturais. O aumento da expectativa de vida da população e o crescimento econômico desordenado agravaram, ainda mais, os danos ambientais causados pelo Estado Liberal.

Esses modelos de Estados foram construídos através de uma visão individual e patrimonialista, com poucas preocupações com o coletivo. Os conceitos de Estado de Direito e o direito à propriedade construídos sob a luz do liberalismo e ideais dos contratualistas, culminaram com o uso irracional dos recursos naturais e aumento da desigualdade social, levando-se a crise ambiental e social existentes atualmente.

A crise ambiental surge justamente pelo conceito de direito de propriedade que permitia o uso irracional e egoísta dos recursos naturais. As pessoas por serem donas de terminadas áreas, entendiam que ali poderiam fazer o que bem entendessem sem haver qualquer preocupação com as demais pessoas.

O pensamento individualista é o grande obstáculo a ser superado para a promoção e preservação do meio ambiente. O pensador francês Edgar Morin aponta como que a sociedade atual caminha para o caos:

A humanidade mergulha num caos que poderá destruí-la, sendo o termo caos entendido aqui como a unidade indistinta da criação e da destruição. Não se sabe o que virá,

\footnotetext{
${ }^{3}$ ABREU, Pedro Manoel. Processo e Democracia: o processo jurisdicional como um lócus da democracia participativa e da cidadania inclusiva no estado democrático de direito. São Paulo: Conceito Editorial, 2011, p.100.
} 
PEREIRA, Diego Emmanoel Serafim. O dever de participação na proteção em matéria ambiental na legislação brasileira. Revista Eletrônica Direito e Política, Programa de Pós-Graduação Stricto Sensu em Ciência Jurídica da UNIVALI, Itajaí, v.10, n.1, edição especial de 2015. Disponível em: www.univali.br/direitoepolitica - ISSN 1980-7791.

mas se sabe que há e haverá enormes desperdícios de energia, de boa vontade, de vidas, e que os progressos atuais escapam ao pensamento e à sabedoria humanos. A insustentável complexidade do mundo sufoca nossas mentes. ${ }^{4}$

A vida no planeta caminha para a insustentabilidade em todas as suas dimensões se não houver uma mudança nos paradigmas que norteiam os hábitos e as ações no mundo. Por essa razão, precisa haver uma transformação no Estado contemporâneo que venha a levar em conta os riscos ambientais. Atualmente o meio ambiente passou a ver visto como um bem jurídico que necessita de proteção pelo Direito, pois o meio ambiente é dotado de um valor intrínseco, e não somente como um instrumento para a satisfação da vida humana. ${ }^{5}$

A mudança não parte e compete apenas ao Estado, mas aos indivíduos que devem adotar uma postura que contribua para a preservação do planeta. Essa mudança de paradigma seria o maior desafio para a concretização desse Estado, que pressupõe que cada indivíduo atue em parceria com o Estado, assumindo para si a responsabilidade de cuidado com o outro e a preservação e valoração do meio ambiente. ${ }^{6}$

Para Leite e Ayala ${ }^{7}$ a construção de um Estado de Direito Ambiental exige uma efetiva colaboração entre o Estado e o cidadão na gestão e no controle ambiental, na qual, a vida digna requer uma ação política e organizada do homem, ampliando o exercício da cidadania, na luta pela preservação ambiental e do Direito do Ambiente, evitando desigualdades, opressões e a devastação do ambiente. Na construção do Estado de Direito Ambiental, o meio ambiente é tido como bem comum do povo e vital para a sadia qualidade de vida da população. O Estado Ambiental deve ser democrático e constituído por leis que permitam a intervenção em atividades econômicas que degradem o Meio Ambiente e que

\footnotetext{
${ }^{4}$ MORIN, Edgar. O método 5: a humanidade da humanidade: a identidade humana.4. ed. Porto Alegre: Sulina, 2007, p. 241.

${ }^{5}$ COSTA NETO, Nicolao Dino de Castro e. Proteção jurídica do meio ambiente. Belo Horizonte, MG: Del Rey, 2003. p.4.

${ }^{6}$ RUSCHEL, Caroline Vieira. Parceria Ambiental. Cidade: Juará, ano, p.73.

7 LEITE, José Rubens Morato; AYALA, Patryck de Araújo. Direito ambiental na sociedade de risco, p.321.
} 
PEREIRA, Diego Emmanoel Serafim. O dever de participação na proteção em matéria ambiental na legislação brasileira. Revista Eletrônica Direito e Política, Programa de Pós-Graduação Stricto Sensu em Ciência Jurídica da UNIVALI, Itajaí, v.10, n.1, edição especial de 2015. Disponível em: www.univali.br/direitoepolitica - ISSN 1980-7791.

ponham em risco a sociedade. O Estado Ambiental tem como um dos pilares a responsabilidade socioambiental intergeracional, não se limitando a atender as necessidades da presente geração, mas também das gerações futuras.

Ruschel $^{8}$ indica que esse Estado necessita de um trabalho em parceria entre o Poder Público e a sociedade civil, ao contrário do Estado Liberal e Estado Social, no qual, Estado e Sociedade trabalhavam isoladamente ou em que o Estado apenas se limitava a ser um garantidor de direitos. A visão individualista contida no Estado Liberal e Social daria lugar a um pensamento solidário e cooperativo entre Estado e Sociedade.

Uma diferença entre esse novo modelo de Estado com os modelos anteriores é que, enquanto, os modelos anteriores visavam principalmente criar e efetivar direitos que não existiam ou que não estavam ao alcance da população, como por exemplo, saúde, moradia, educação, o Estado Ambiental tem a principal finalidade de garantir a existência do bem ambiental e recuperar o que já foi degradado. ${ }^{9}$

Para que haja uma participação social no Estado é necessária, primeiramente, a tomada de consciência que o Mundo passa por uma crise ambiental. Essa crise é agravada a cada dia e a demora em se conscientizar e em se tomar medidas que inibam ou ao menos diminuam com a degradação, aumentam a crise, tornando cada vez mais irreversíveis os danos causados.

Segundo Leite e Ayala ${ }^{10}$ o Estado de Estado de Direito Ambiental permitira uma mudança radical nas estruturas existentes da sociedade organizada, pois com a conscientização da crise ambiental, se exigirá uma cidadania participativa, na qual, estimulará o aumento de ações conjuntas entre o Estado e a coletividade na proteção ambiental. A solução para a crise ambiental seria a mudança da

\footnotetext{
${ }^{8}$ RUSCHEL, Caroline Vieira. Parceria Ambiental, p.27.

${ }^{9}$ LEITE, José Rubens Morato; AYALA, Patryck de Araújo. Direito ambiental na sociedade de risco, p.39.

${ }^{10}$ LEITE, José Rubens Morato; AYALA, Patryck de Araújo. Direito ambiental na sociedade de risco, p.39.
} 
PEREIRA, Diego Emmanoel Serafim. O dever de participação na proteção em matéria ambiental na legislação brasileira. Revista Eletrônica Direito e Política, Programa de Pós-Graduação Stricto Sensu em Ciência Jurídica da UNIVALI, Itajaí, v.10, n.1, edição especial de 2015. Disponível em: www.univali.br/direitoepolitica - ISSN 1980-7791.

responsabilidade da preservação ambiental, que não se limitaria ao Estado, mas a uma gestão solidária e participativa entre Estados e cidadãos.

Isso só ocorre porque no Estado Ambiental, o bem ambiental pertence à coletividade e não ao Poder Público ou a algum particular. Uma vez que o bem ambiental pertence à coletiva, a sua proteção deve, também, ser compartilhada por todos os componentes da sociedade, na qual, se exige uma responsabilidade solidária na gestão ambiental com a ação de vários atores como Poder Público, Sociedade Civil e Mercado.

A necessidade da transformação do Estado, que seja menos capitalista e pare de estimular ao consumo desenfreado através do discurso do crescimento econômico, para um Estado voltado ao social, transformando a produção e o consumo, de modo a garantir a proteção ambiental, bem como estimular a participação do indivíduo na conservação do meio ambiente como meio legítimo do exercício da cidadania.

\section{O DEVER DE PARTICIPAÇÃO DO CIDADÃO NA PROTEÇÃO AMBIENTAL}

As transformações sociais promovidas no Estado Social e aos avanços tecnológicos do século XX trouxeram o aumento do consumo dos recursos naturais no planeta, o que acarretou no risco de um colapso e da inviabilidade da vida humana. Convém observar que maior parte da evolução histórica se deu a luz do pensamento antropocêntrico, no qual, o Homem era o centro do Universo e poderia dispor livremente dos recursos existentes.

Tal visão fez com que o homem sempre buscasse dominar a natureza. O poder sobre a natureza trouxe inúmeros malefícios destruindo florestas, extinguindo espécies, contaminando o solo, etc. Os desastres e a escassez de recursos naturais colocaram em xeque os pensamentos e as ações humanas, necessitando de novas transformações na maneira de pensar a existência humana e sua relação com a Terra. Um novo comportamento ético da sociedade se revela 
PEREIRA, Diego Emmanoel Serafim. O dever de participação na proteção em matéria ambiental na legislação brasileira. Revista Eletrônica Direito e Política, Programa de Pós-Graduação Stricto Sensu em Ciência Jurídica da UNIVALI, Itajaí, v.10, n.1, edição especial de 2015. Disponível em: www.univali.br/direitoepolitica - ISSN 1980-7791.

necessário, pois não será possível manter o bem-estar produzido no Estado Social com um comportamento insaciável e consumista como nos dias atuais.

Milaré ${ }^{11}$ indica que a mudança de conceitos e comportamentos é o grande problema a ser enfrentado, ainda mais, quando deve ser feita em um curto espaço de tempo, pois não mais se poder esperar e deixar que os danos ambientais cresçam e causem ainda mais impactos. Essas mudanças estariam de acordo com uma nova Ética que seria uma Ética Ambiental tida como uma "ética de terceira geração", que se concentra na sobrevivência do planeta Terra com todos os seus ecossistemas e da humanidade. A Ética Ambiental é analisada sob três prismas: a abordagem social do meio ambiente como patrimônio da coletividade, a perspectiva política do meio ambiente como objeto da gestão pública e pelo enfoque ecocêntrico do meio ambiente através de uma ética da vida $^{12}$

A dimensão ética da sustentabilidade, conforme a obra de Freitas ${ }^{13}$, é encarada no sentido de que todos os seres possuem uma ligação intersubjetiva e natural, que se dá através da solidariedade, na qual a cooperação entre os indivíduos surge, então, como um dever favorável à continuidade da vida. Esse dever de cooperar nasce em razão da crise ambiental, pois sem a cooperação não será possível enfrentar e solucionar os problemas existentes. Compete então aos cidadãos adotarem uma postura ativa e participativa na proteção ambiental. A participação do cidadão é tida como um dever social que carrega consigo a idéia de solidariedade. "O que se espera da sociedade é justamente uma tomada de posição, ativa, altruísta, ética e participativa, mormente quando estamos diante de valores sagrados e essenciais à preservação da vida." 14

11 MILARÉ, Édis. Direito do ambiente: a gestão ambiental em foco - doutrina, jurisprudência, glossário. 8. ed. rev. atual. ref. São Paulo: Revista dos tribunais, 2013, p.143.

12 MILARÉ, Édis. Direito do ambiente: a gestão ambiental em foco - doutrina, jurisprudência, glossário, p.155.

${ }^{13}$ FREITAS, Juarez. Sustentabilidade: direito ao futuro. Belo Horizonte: Editora Fórum, 2011, p.57.

${ }^{14}$ RODRIGUES, Marcelo Abelha. Instituições de Direito Ambiental. Vol. 1. São Paulo: Max Limonad, 2002, p. 255. 
PEREIRA, Diego Emmanoel Serafim. O dever de participação na proteção em matéria ambiental na legislação brasileira. Revista Eletrônica Direito e Política, Programa de Pós-Graduação Stricto Sensu em Ciência Jurídica da UNIVALI, Itajaí, v.10, n.1, edição especial de 2015. Disponível em: www.univali.br/direitoepolitica - ISSN 1980-7791.

Ainda, segundo o autor, há dever ético de sustentabilidade ativa, pois existe um dever ético de ser benéfico para todos os seres, que não se limita em apenas deixar de tomar atitudes que venham a prejudicar os demais indivíduos e o meio ambiente. Uma atitude eticamente sustentável e de acordo com o novo paradigma "é aquela que consiste em agir de modo tal que possa ser universalizada a produção do bem-estar duradouro, no íntimo e na interação com a natureza" ${ }^{15}$ Assim, uma atitude ética busca alcançar bem-estar íntimo e bemestar social e não apenas um crescimento econômico sem se preocupar com as questões ambientais.

Para encarar essa crise ambiental, Morin ${ }^{16}$ trata da política de civilização que tem como objetivo a qualidade de vida, manifestada no chamado bem-viver. "La política de civilización parte de los desafíos, de las amenazas, pero tambíen de las necesidades que surgen frente a estos desafíos y a estas amenazas." 17

A política de civilização não é uma política restrita a intelectuais, pois pressupõem a adesão dos cidadãos, abrindo uma via de esperança estimulando boas ações entre os indivíduos. A solidariedade entre os indivíduos, na qual cada um é responsável pelo bem-estar do outro é o ponto principal da conduta moral que se tem com essa nova ética. A restauração da solidariedade e da responsabilidade para com o outro é vista como um círculo virtuoso que promove a qualidade de vida e o bem-viver, ao contrário do círculo vicioso dos dias atuais no qual a automatização dos processos políticos e sociais e a irresponsabilidade com o próximo geram uma sociedade egoísta e individualista. ${ }^{18}$

A responsabilidade do cidadão na proteção do meio ambiente e com os demais indivíduos trata-se de um sistema de responsabilidade compartilhada, atribuindo a todos a proteção do meio ambiente. Não se pode atribuir exclusivamente ao Estado a titularidade do dever e a obrigação de garantia dos direitos relacionados ao meio ambiente, essa repartição das responsabilidades ambientais vem ao

\footnotetext{
${ }^{15}$ FREITAS, Juarez. Sustentabilidade: direito ao futuro, p. 58.

${ }^{16}$ MORIN, Edgar. Para una política de la civilizacion. Barcelona: Paidos, 2009. p.99.

${ }^{17}$ MORIN, Edgar. Para una política de la civilización, p.100.

${ }^{18}$ MORIN, Edgar. Para una política de la civilización, p.100-101.
} 
PEREIRA, Diego Emmanoel Serafim. O dever de participação na proteção em matéria ambiental na legislação brasileira. Revista Eletrônica Direito e Política, Programa de Pós-Graduação Stricto Sensu em Ciência Jurídica da UNIVALI, Itajaí, v.10, n.1, edição especial de 2015. Disponível em: www.univali.br/direitoepolitica - ISSN 1980-7791.

encontro de democratizar a democracia fundada na participação, descentralização e coletivização das demandas e pretensões ${ }^{19}$. Neste mesmo sentido, Ferrer também se posiciona "La tarea de defender y preservar el medio ambiente no es, no puede ser, exclusiva de los poderes públicos. Todos los ciudadanos estamos implicados y deberíamos adoptar actitudes activas al respecto." 20

$\mathrm{Na}$ sociedade atual espera-se uma postura ativa dos cidadãos na defesa e proteção ambiental. Há um dever ético para com o planeta do qual nenhum cidadão pode negar ou se omitir, esperando que apenas o Estado adote medidas preventivas e protecionistas ao meio ambiente. $O$ direito ao meio ambiente equilibrado é um direito de todos, da mesma forma que o dever de proteção é também um dever de toda a sociedade. Para que ocorra uma participação efetiva, possibilitando o cumprimento do dever de proteção ambiental, é preciso que primeiramente haja acesso à informação.

El acceso a la información relevante es el elemento fundamental para permitir una participación realmente eficiente. Sin embargo, a pesar del consenso existente a la hora de vincular la eficacia de la participación a la existencia de un flujo de información suficiente que garantice que los ciudadanos puedan ser consientes de cómo una decisión puede afectar a sus intereses, la información a partir de la que puede fundarse la actividad participativa es, en mucha ocasiones, insuficiente, difícilmente accesible o sencillamente incomprensible, de manera que el ciudadano deja de estar en condicionas de participar de manera efectiva en el procedimiento de toma de decisiones. ${ }^{21}$

O acesso facilitado a informações de cunho ambiental permite o maior engajamento dos atores sociais na implementação de soluções para os

\footnotetext{
${ }^{19}$ LEITE, José Rubens Morato; AYALA, Patryck de Araújo. Direito ambiental na sociedade de risco, p.323.

20 FERRER, Gabriel. La construcción del Derecho Ambiental. Disponível em: <http://www.dda.ua.es/documentos/construccion_derecho_ambiental.pdf> Acesso em: 07 jul. 2014.

${ }^{21}$ MANZANO, Jordi Jaria i. El fundamento constitucional de los derechos de participación en materia de medio ambiente y su desarrollo en la ley 27/2006. In: SOLÉ, Antoni Pigrau (Org). Acceso a la información, participación pública y acceso a la justicia en materia de medio ambiente: diez años del Convenio de Aahus.Barcelona: Ed. Atelier , 2008, p. 134-135.
} 
PEREIRA, Diego Emmanoel Serafim. O dever de participação na proteção em matéria ambiental na legislação brasileira. Revista Eletrônica Direito e Política, Programa de Pós-Graduação Stricto Sensu em Ciência Jurídica da UNIVALI, Itajaí, v.10, n.1, edição especial de 2015. Disponível em: www.univali.br/direitoepolitica - ISSN 1980-7791.

problemas ambientais. Somente haverá cidadania ativa se houver a participação de todos, que dependerá das informações que os cidadãos tenham a disposição.

A respeito dessa postura ativa da sociedade Lizarraga e Espinosa apontam que fenômeno participativo é um dos elementos principais na política atual, no qual, a interação e cooperação entre o Estado e a sociedade ganham um destaque ainda maior em se tratando de meio ambiente. Citam, ainda, que a sociedade civil tem um papel de liderança na elaboração de políticas públicas na área ambiental, isso ocorre justamente pela dimensão pública da proteção ambiental e pela aplicação do princípio da responsabilidade compartilhada que pressupõe a participação pública nas decisões que possam gerar um impacto ambiental significativo. As incertezas que norteiam a sociedade de risco acabam por estimular um maior envolvimento da sociedade na conscientização dos riscos ambientais. A busca por resoluções dessas questões por parte da sociedade gera uma maior sensibilização, educação e conscientização da importância da preservação ambiental. ${ }^{22}$

O dever fundamental de proteção ao meio ambiente acaba por beneficiar toda a coletividade, uma vez que, esta associado aos direitos sociais, o que contribui para a formação do Estado de Direito Ambiental. O dever fundamental de proteção ao meio ambiente traz a ideia de solidariedade, que não se limita apenas da relação do cidadão com o Estado, mas também da relação do cidadão com os demais cidadãos e com as demais espécies. A proteção ao meio ambiente é relacionada com a efetivação dos direitos sociais, como saúde, moradia, alimentação, etc., pois esses direitos somente poderão ser oferecidos em um ambiente ecologicamente equilibrado. ${ }^{23}$

Esse dever fundamental pressupõe não apenas um dever com a natureza, mas um dever também com seres humanos. ${ }^{24}$ Um obstáculo para entender e aceitar

\footnotetext{
22 LIZARRAGA, J.A. Razquin; ESPINOSA, A. Ruiz de Apoca. Informacion, participación y justiça en materia de medio ambiente. Pamplona: Editora Aranzadi, 2007. P.34.

${ }^{23}$ FENSTERSEIFER, Tiago. Direitos fundamentais e proteção ambiental - A dimensão ecológica da dignidade humana no marco jurídico-constitucional do Estado Socioambiental de Direito. Porto Alegre: Livraria do Advogado, 2008, p. 75.

${ }^{24}$ RUSCHEL, Caroline Vieira. Parceria Ambiental, p.134.
} 
PEREIRA, Diego Emmanoel Serafim. O dever de participação na proteção em matéria ambiental na legislação brasileira. Revista Eletrônica Direito e Política, Programa de Pós-Graduação Stricto Sensu em Ciência Jurídica da UNIVALI, Itajaí, v.10, n.1, edição especial de 2015. Disponível em: www.univali.br/direitoepolitica - ISSN 1980-7791.

que a proteção ao meio ambiente é um direito-dever é justamente pelo fato da sociedade pensar em apenas conquistar e gozar de direitos, os quais competiam ao Estado garantir. ${ }^{25} \mathrm{~A}$ transformação desse paradigma ocorre lentamente e esta atrelada a conscientização dos riscos ambientais e de uma nova Ética, na qual haja mais solidariedade para com os demais indivíduos e com o Estado.

\section{O DEVER DE PARTICIPAÇÃO NA LEGISLAÇÃO BRASILEIRA}

O dever fundamental imposto a sociedade de participar da proteção ambiental encontra-se previsto na Constituição e em diversas leis no Brasil. A obrigatoriedade de participação da sociedade nas questões ambientais é um princípio constitucional. O artigo 225 da $\mathrm{CF}^{26}$ estabelece que cabe não somente ao Poder Público, mas também à coletividade o dever de proteger e preservar o meio ambiente para as gerações presentes e futuras. Reconhece-se o meio ambiente adequado como um direito-dever, e como contraprestação desse direito se supõe o dever de conservação do meio ambiente como obrigação de todos os cidadãos.

A participação em matéria ambiental é um princípio constitucional e expressa a ideia de que para a resolução dos problemas ambientais, a cooperação entre o Estado e a sociedade se dá com participação dos diferentes grupos sociais na formulação e na execução da política ambiental, nas esferas federal, estadual e municipal. Dessa forma, se exige uma postura ativa, pois é um dever do cidadão participar na proteção ambiental garantindo o meio ambiente equilibrado para as presentes e futuras gerações. ${ }^{27}$

\footnotetext{
${ }^{25}$ RUSCHEL, Caroline Vieira. Parceria Ambiental, p.187.

${ }^{26}$ Art. 225. Todos têm direito ao meio ambiente ecologicamente equilibrado, bem de uso comum do povo e essencial à sadia qualidade de vida, impondo-se ao Poder Público e à coletividade o dever de defendê-lo e preservá- lo para as presentes e futuras gerações. BRASIL. Constituição da República Federativa do Brasil de 5 de outubro de 1988 . Disponível em: <http://www.planalto.gov.br/ccivil_03/constituicao/constituicao.htm >. Acesso em: 05 jul. 2014.

${ }^{27}$ MIRRA, Álvaro Luiz Valery. Participação, processo civil e defesa do meio ambiente. São Pulo: Letras Jurídicas, 2011. p.99.
} 
PEREIRA, Diego Emmanoel Serafim. O dever de participação na proteção em matéria ambiental na legislação brasileira. Revista Eletrônica Direito e Política, Programa de Pós-Graduação Stricto Sensu em Ciência Jurídica da UNIVALI, Itajaí, v.10, n.1, edição especial de 2015. Disponível em: www.univali.br/direitoepolitica - ISSN 1980-7791.

Conforme já dito, o dever constitucional exige da coletividade uma postura ativa e que se abandone a postura passiva, da qual, apenas competiria ao Estado a proteção ambiental. A Constituição Federal busca a participação de todos na defesa do meio ambiente, pois é a melhor maneira de se tratar das questões ambientais. "O problema de política ambiental só poderá ser resolvido quando reconhecida a unidade de política entre cidadãos e Estado e meio ambiente, e garantindo os instrumentos de ação conjunta." 28

O texto constitucional não apenas reconhece a tutela ao direito em questão, mas também a garantia de uma série de vias e fórmulas que permitam a participação do cidadão sobre as questões relativas ao meio ambiente. Exige-se do Estado a elaboração de normas voltadas a concretização e a cooperação dos cidadãos nas decisões na esfera ambiental. ${ }^{29}$ Para que esse dever possa ser cumprido é preciso uma série de mecanismos e instrumentos que contribuam para a participação pública. Compete ao Estado à elaboração de leis que permitam a participação. A obrigatoriedade do Estado em proporcionar leis que permitam a conscientização e a participação encontra-se descrita no Princípio 10 da Declaração do Rio ${ }^{30}$ : "Os Estados irão facilitar e estimular a conscientização e participação pública, colocando a informação à disposição de todos." ${ }^{31}$

Pode-se citar a lei 9.795/99 ${ }^{32}$ que institui a Política Nacional de Educação Ambiental que estabelece ao Estado definir políticas públicas que promovam a

\footnotetext{
${ }^{28}$ LEITE, José Rubens Morato; AYALA, Patryck de Araújo. Direito ambiental na sociedade de risco, p.40.

${ }^{29}$ LEITE, José Rubens Morato; AYALA, Patryck de Araújo. Direito ambiental na sociedade de risco, p.40-41.

30 Princípio $10 \mathrm{~A}$ melhor maneira de tratar questões ambientais é assegurar a participação, no nível apropriado, de todos os cidadãos interessados. No nível nacional, cada indivíduo deve ter acesso adequado a informações relativas ao meio ambiente de que disponham as autoridades públicas, inclusive informações sobre materiais e atividades perigosas em suas comunidades, bem como a oportunidade de participar de processos decisórios. Os Estados irão facilitar e estimular a conscientização e participação pública, colocando a informação à disposição de todos. Deve ser proporcionado acesso efetivo a mecanismos judiciais e administrativos, inclusive no que se refere à compensação e reparação de danos.
}

31 ORGANIZAÇÃO DAS NAÇÕES UNIDAS. Declaração do Rio de Janeiro sobre Meio Ambiente e Desenvolvimento (Declaração do Rio), adotada de 3 a 14 de junho de 1992. Disponível em: < http://www.onu.org.br/rio20/img/2012/01/rio92.pdf >. Acesso em: 5 jul. 2014

${ }^{32}$ BRASIL. Lei Federal n. 9.795, de abril de 1999. Dispõe sobre a educação ambiental, institui a Política Nacional de Educação Ambiental e dá outras providências. Disponível em: < http://www.planalto.gov.br/ccivil_03/leis/19795.htm>. Acesso em: 07 jul. 2014. 
PEREIRA, Diego Emmanoel Serafim. O dever de participação na proteção em matéria ambiental na legislação brasileira. Revista Eletrônica Direito e Política, Programa de Pós-Graduação Stricto Sensu em Ciência Jurídica da UNIVALI, Itajaí, v.10, n.1, edição especial de 2015. Disponível em: www.univali.br/direitoepolitica - ISSN 1980-7791.

educação ambiental e o engajamento da sociedade na conservação, recuperação e melhoria do meio ambiente. A conscientização é o primeiro passo para que haja uma participação popular efetiva na defesa do meio ambiente. Referida lei prevê em seu artigo 30, inciso VI, que incube "à sociedade como um todo, manter atenção permanente à formação de valores, atitudes e habilidades que propiciem a atuação individual e coletiva voltada para a prevenção, a identificação e a solução de problemas ambientais." ${ }^{33}$

Entre os objetivos da lei de educação ambiental estão o de se estimular o fortalecimento da uma consciência crítica, incentivar a participação individual e coletiva e fortalecer a cidadania e a solidariedade com fundamentos para o futuro da humanidade. ${ }^{34} \mathrm{O}$ Poder Público desenvolverá práticas educativas, seja pela educação formal ou pela educação não-formal, com objetivo de sensibilizar a coletividade das questões ambientais estimulando, assim, a participação na defesa da qualidade do meio.

33 Art. $3^{\circ}$ Como parte do processo educativo mais amplo, todos têm direito à educação ambiental, incumbindo: I - ao Poder Público, nos termos dos arts. 205 e 225 da Constituição Federal, definir políticas públicas que incorporem a dimensão ambiental, promover a educação ambiental em todos os níveis de ensino e o engajamento da sociedade na conservação, recuperação e melhoria do meio ambiente.

34 Art. 5ำ São objetivos fundamentais da educação ambiental:

I - o desenvolvimento de uma compreensão integrada do meio ambiente em suas múltiplas e complexas relações, envolvendo aspectos ecológicos, psicológicos, legais, políticos, sociais, econômicos, científicos, culturais e éticos;

II - a garantia de democratização das informações ambientais;

III - o estímulo e o fortalecimento de uma consciência crítica sobre a problemática ambiental e social;

IV - o incentivo à participação individual e coletiva, permanente e responsável, na preservação do equilíbrio do meio ambiente, entendendo-se a defesa da qualidade ambiental como um valor inseparável do exercício da cidadania;

V - o estímulo à cooperação entre as diversas regiões do País, em níveis micro e macrorregionais, com vistas à construção de uma sociedade ambientalmente equilibrada, fundada nos princípios da liberdade, igualdade, solidariedade, democracia, justiça social, responsabilidade e sustentabilidade;

VI - o fomento e o fortalecimento da integração com a ciência e a tecnologia;

VII - o fortalecimento da cidadania, autodeterminação dos povos e solidariedade como fundamentos para o futuro da humanidade. 
PEREIRA, Diego Emmanoel Serafim. O dever de participação na proteção em matéria ambiental na legislação brasileira. Revista Eletrônica Direito e Política, Programa de Pós-Graduação Stricto Sensu em Ciência Jurídica da UNIVALI, Itajaí, v.10, n.1, edição especial de 2015. Disponível em: www.univali.br/direitoepolitica - ISSN 1980-7791.

A Política Nacional de Educação Ambiental está de acordo com os anseios da Política Nacional do Meio Ambiente - PNMA - lei 6.938/81 ${ }^{35}$ que dispõe que a educação ambiental em todos os níveis de ensino deve promover a participação ativa da sociedade.

A PNMA criou o Conselho Nacional do Meio Ambiente - CONAMA - que é um órgão consultivo e deliberativo do Sistema Nacional do Meio Ambiente SISNAMA. O CONAMA é um colegiado composto por setores como órgãos federais, estaduais e municipais e do setor empresarial e da sociedade civil. O CONAMA possui vinte e dois representantes de entidades de trabalhadores e da sociedade civil e oito representantes de entidades empresariais. ${ }^{36}$ Há, ainda, conselhos do meio ambiente em esferas estaduais e municipais. A criação de conselhos permite que a sociedade civil participe e delibere sobre as políticas ambientais.

Entre outras leis ambientais que buscam a proteção dos recursos naturais podese citar a Lei da Gestão das Florestas Públicas - Lei n. ${ }^{0} 11.284 / 2006^{37}$, que instituiu um órgão consultivo com representantes do Poder Público e da sociedade civil, para assessorar, avaliar e propor diretrizes para a gestão de florestas públicas. Referida lei criou o Fundo Nacional de Desenvolvimento Florestal - FNDF- que contém um conselho consultivo que possui representantes da sociedade civil com a função de opinar sobre a distribuição dos seus recursos

\footnotetext{
35 Art. 2, inciso X: a educação ambiental a todos os níveis de ensino, inclusive a educação da comunidade, objetivando capacitá-la para participação ativa na defesa do meio ambiente.

${ }^{36}$ Portaria Ministério do Meio Ambiente no 452, novembro de 2011. Regimento interno do Conselho Nacional do Meio Ambiente. Disponível em: <http://www.mma.gov.br/port/conama/legiabre.cfm?codlegi=656>. Acesso em: 07 jul. 2014.

37 BRASIL. Lei Federal n. 11.284, de março de 2006. Dispõe sobre a gestão de florestas públicas para a produção sustentável; institui, na estrutura do Ministério do Meio Ambiente, o Serviço Florestal Brasileiro - SFB; cria o Fundo Nacional de Desenvolvimento Florestal - FNDF; altera as Leis nos 10.683, de 28 de maio de 2003, 5.868, de 12 de dezembro de 1972, 9.605, de 12 de fevereiro de 1998, 4.771, de 15 de setembro de 1965, 6.938, de 31 de agosto de 1981, e 6.015, de 31 de dezembro de 1973; e dá outras providências. Disponível em: < http://www.planalto.gov.br/ccivil_03/_ato2004-2006/2006/lei/l11284.htm>. Acesso em: 07 jul. 2014.
} 
PEREIRA, Diego Emmanoel Serafim. O dever de participação na proteção em matéria ambiental na legislação brasileira. Revista Eletrônica Direito e Política, Programa de Pós-Graduação Stricto Sensu em Ciência Jurídica da UNIVALI, Itajaí, v.10, n.1, edição especial de 2015. Disponível em: www.univali.br/direitoepolitica - ISSN 1980-7791.

e a avaliação da aplicação de recursos ${ }^{38}$. Prevê, ainda, que as comunidades locais poderão participar de licitações que estabeleçam as concessões florestais ${ }^{39}$.

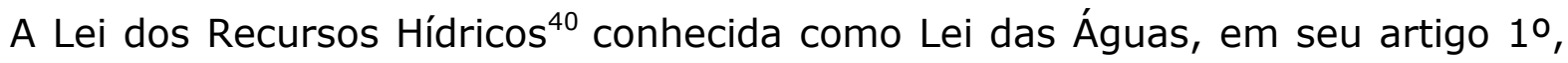
inciso VI, disciplina que a gestão dos recursos hídricos deve ser descentralizada e contar com a participação do Poder Público, dos usuários e das comunidades. A Lei das Unidades de Conservação ${ }^{41}$ ao estabelecer o Sistema Nacional de Unidades de Conservação da Natureza - SNUC, prevê que o SNUC seja regido por diretrizes que assegurem a participação efetiva das populações locais na criação, implantação e gestão das unidades de conservação; bem como que a cooperação e o incentivo da participação de ONG's e da sociedade civil na gestão da conservação da natureza. ${ }^{42}$

\footnotetext{
${ }^{38}$ Art.41, § 2ํㅡ O FNDF contará com um conselho consultivo, com participação dos entes federativos e da sociedade civil, com a função de opinar sobre a distribuição dos seus recursos e a avaliação de sua aplicação.
}

39 Art. $6^{\circ} \S 2^{\circ}$ Sem prejuízo das formas de destinação previstas no caput deste artigo, as comunidades locais poderão participar das licitações previstas no Capítulo IV deste Título, por meio de associações comunitárias, cooperativas ou outras pessoas jurídicas admitidas em lei.

40 BRASIL. Lei Federal n.9.433, de janeiro de 1997. Institui a Política Nacional de Recursos Hídricos, cria o Sistema Nacional de Gerenciamento de Recursos Hídricos, regulamenta o inciso XIX do art. 21 da Constituição Federal, e altera o art. $1^{\circ}$ da Lei no 8.001, de 13 de março de 1990, que modificou a Lei no 7.990, de 28 de dezembro de 1989. Disponível em: http://www.planalto.gov.br/ccivil_03/leis/19433.htm>. Acesso em: 07 jul. 2014.

${ }^{41}$ BRASIL. Lei Federal n.9.433, de janeiro de 1997. Regulamenta o art. 225, § $1^{\circ}$, incisos I, II, III e VII da Constituição Federal, institui o Sistema Nacional de Unidades de Conservação da Natureza e dá outras providências.Disponível em: http://www.planalto.gov.br/ccivil_03/leis/19985.htm>. Acesso em: 07 jul. 2014.

${ }^{42}$ Art. $5^{\circ}$ O SNUC será regido por diretrizes que:

I - assegurem que no conjunto das unidades de conservação estejam representadas amostras significativas e ecologicamente viáveis das diferentes populações, habitats e ecossistemas do território nacional e das águas jurisdicionais, salvaguardando o patrimônio biológico existente;

II - assegurem os mecanismos e procedimentos necessários ao envolvimento da sociedade no estabelecimento e na revisão da política nacional de unidades de conservação;

III - assegurem a participação efetiva das populações locais na criação, implantação e gestão das unidades de conservação;

IV - busquem o apoio e a cooperação de organizações não-governamentais, de organizações privadas e pessoas físicas para o desenvolvimento de estudos, pesquisas científicas, práticas de educação ambiental, atividades de lazer e de turismo ecológico, monitoramento, manutenção e outras atividades de gestão das unidades de conservação;

$\mathrm{V}$ - incentivem as populações locais e as organizações privadas a estabelecerem e administrarem unidades de conservação dentro do sistema nacional. 
PEREIRA, Diego Emmanoel Serafim. O dever de participação na proteção em matéria ambiental na legislação brasileira. Revista Eletrônica Direito e Política, Programa de Pós-Graduação Stricto Sensu em Ciência Jurídica da UNIVALI, Itajaí, v.10, n.1, edição especial de 2015. Disponível em: www.univali.br/direitoepolitica - ISSN 1980-7791.

O Estatuto da Cidade $^{43}$ - Lei n. ${ }^{0}$ 10.257/2001- expõe entre as suas diretrizes a gestão democrática da cidade através da participação da sociedade na elaboração dos planos e programas de desenvolvimento urbano; além da cooperação entre os governos, a iniciativa privada e os demais setores da sociedade civil no processo de urbanização ${ }^{44}$. Os instrumentos da política urbana devem permitir a participação da comunidade na gestão do meio urbano. ${ }^{45} \mathrm{Na}$ elaboração do plano diretor deve-se permitir a participação da sociedade através de audiências públicas e no acesso e na publicidade de informações. ${ }^{46}$

A Lei $n .{ }^{012.305 / 2010^{47}}$ que trata sobre a destinação dos resíduos sólidos versa que o Plano Nacional de Resíduos Sólidos será elaborado através de um processo de mobilização e participação social ${ }^{48}$. Essa lei dispõe que são princípios da Política Nacional de Resíduos Sólidos o direito da sociedade à informação e ao controle social, definindo controle social como "conjunto de mecanismos e

43 BRASIL. Lei Federal n.9.985, de julho de 2000. Regulamenta os arts. 182 e 183 da Constituição Federal, estabelece diretrizes gerais da política urbana e dá outras providências.. Disponível em: <http://www.planalto.gov.br/ccivil_03/leis/leis_2001/l10257.htm>. Acesso em: 07 jul. 2014.

${ }^{44}$ Art. $2^{\circ}$ A política urbana tem por objetivo ordenar o pleno desenvolvimento das funções sociais da cidade e da propriedade urbana, mediante as seguintes diretrizes gerais:

(...)

II - gestão democrática por meio da participação da população e de associações representativas dos vários segmentos da comunidade na formulação, execução e acompanhamento de planos, programas e projetos de desenvolvimento urbano;

III - cooperação entre os governos, a iniciativa privada e os demais setores da sociedade no processo de urbanização, em atendimento ao interesse social;

45 Art. $4 \S 3^{\circ}$ Os instrumentos previstos neste artigo que demandam dispêndio de recursos por parte do Poder Público municipal devem ser objeto de controle social, garantida a participação de comunidades, movimentos e entidades da sociedade civil.

${ }^{46} \S 4^{\circ}$ No processo de elaboração do plano diretor e na fiscalização de sua implementação, os Poderes Legislativo e Executivo municipais garantirão:

I - a promoção de audiências públicas e debates com a participação da população e de associações representativas dos vários segmentos da comunidade;

II - a publicidade quanto aos documentos e informações produzidos;

III - o acesso de qualquer interessado aos documentos e informações produzidos.

${ }^{47}$ BRASIL. Lei Federal n.12.305, de agosto de 2010. Institui a Política Nacional de Resíduos Sólidos; altera a Lei № 9.605, de 12 de fevereiro de 1998; e dá outras providências. Disponível em: <http://www.planalto.gov.br/ccivil_03/_ato2007-2010/2010/lei/l12305.htm>. Acesso em: 07 jul. 2014.

48 Art. 15. Parágrafo único. O Plano Nacional de Resíduos Sólidos será elaborado mediante processo de mobilização e participação social, incluindo a realização de audiências e consultas públicas. 
PEREIRA, Diego Emmanoel Serafim. O dever de participação na proteção em matéria ambiental na legislação brasileira. Revista Eletrônica Direito e Política, Programa de Pós-Graduação Stricto Sensu em Ciência Jurídica da UNIVALI, Itajaí, v.10, n.1, edição especial de 2015. Disponível em: www.univali.br/direitoepolitica - ISSN 1980-7791.

procedimentos que garantam à sociedade informações e participação nos processos de formulação, implementação e avaliação das políticas públicas relacionadas aos resíduos sólidos." ${ }^{49}$

A Política Nacional de Mudanças Climáticas, instituída pela lei n. ${ }^{0} 12.187 / 2009^{50}$, trata da participação cidadã como um de seus princípios, apontando que "todos têm o dever de atuar, em benefício das presentes e futuras gerações, para a redução dos impactos decorrentes das interferências antrópicas sobre o sistema climático." ${ }^{51}$ Entre as diretrizes da Política Nacional sobre Mudança do Clima estão o estímulo e o apoio à participação do setor produtivo, do meio acadêmico e da sociedade civil organizada, no desenvolvimento e na execução de políticas, planos, programas e ações relacionados à mudança do clima ${ }^{52}$.

\section{A Lei Federal n. ${ }^{\circ} 11.445 / 2007^{53}$ - que estabelece as diretrizes para o} saneamento básico e para a política federal de saneamento básico, também, prevê a participação popular como forma de controle social e de preservação do meio ambiente permitindo que usuários ou entidades da sociedade civil e de

\footnotetext{
${ }^{49}$ Art. $3^{\circ}$ Para os efeitos desta Lei, entende-se por: VI - controle social: conjunto de mecanismos e procedimentos que garantam à sociedade informações e participação nos processos de formulação, implementação e avaliação das políticas públicas relacionadas aos resíduos sólidos.
}

50 BRASIL. Lei Federal n.12.187, de dezembro de 2009 Institui a Política Nacional sobre Mudança do Clima - PNMC e dá outras providências.. Disponível em: < http://www.planalto.gov.br/ccivil_03/_ato2007-2010/2009/lei/l12187.htm>. Acesso em: 07 jul. 2014.

51 Art. 3ํ A PNMC e as ações dela decorrentes, executadas sob a responsabilidade dos entes políticos e dos órgãos da administração pública, observarão os princípios da precaução, da prevenção, da participação cidadã, do desenvolvimento sustentável e o das responsabilidades comuns, porém diferenciadas, este último no âmbito internacional, e, quanto às medidas a serem adotadas na sua execução, será considerado o seguinte:

I - todos têm o dever de atuar, em benefício das presentes e futuras gerações, para a redução dos impactos decorrentes das interferências antrópicas sobre o sistema climático;

52 Art. 5ำ São diretrizes da Política Nacional sobre Mudança do Clima: V - o estímulo e o apoio à participação dos governos federal, estadual, distrital e municipal, assim como do setor produtivo, do meio acadêmico e da sociedade civil organizada, no desenvolvimento e na execução de políticas, planos, programas e ações relacionados à mudança do clima.

53 BRASIL. Lei Federal n.11.445, de janeiro de 2007. Estabelece diretrizes nacionais para o saneamento básico; altera as Leis $\mathrm{n}^{\text {os }}$ 6.766, de 19 de dezembro de 1979, 8.036, de 11 de maio de 1990, 8.666, de 21 de junho de 1993, 8.987, de 13 de fevereiro de 1995; revoga a Lei no 6.528, de 11 de maio de 1978; e dá outras providências. Disponível em: < http://www.planalto.gov.br/ccivil_03/_ato2007-2010/2007/lei/l11445.htm>. Acesso em: 07 jul. 2014. 
PEREIRA, Diego Emmanoel Serafim. O dever de participação na proteção em matéria ambiental na legislação brasileira. Revista Eletrônica Direito e Política, Programa de Pós-Graduação Stricto Sensu em Ciência Jurídica da UNIVALI, Itajaí, v.10, n.1, edição especial de 2015. Disponível em: www.univali.br/direitoepolitica - ISSN 1980-7791.

defesa do consumidor participem de órgãos colegiados que buscam regulamentar e fiscalizar as entidades responsáveis pelo saneamento básico ${ }^{54}$.

Já o Código Florestal ${ }^{55}$ tem entre seus princípios que o Poder Público, em suas três esferas, deve atuar com a colaboração da sociedade na criação de políticas públicas voltadas para a preservação e restauração da vegetação. ${ }^{56}$

Como visto, existem no Brasil leis que obrigam a participação dos cidadãos na proteção do meio ambiente. Embora a maior responsabilidade pela proteção ambiental seja do Estado não restam dúvidas que a coletividade, também, possui uma parcela da responsabilidade. A melhor maneira de se promover a participação é conscientizando a comunidade da importância da preservação ambiental para as presentes e futuras gerações. Para que o dever ético de preservar possa ser efetivado são necessários mecanismos que permitam a participação social como de fato a legislação brasileira tem procurado estabelecer. A criação desses mecanismos é que permite a participação efetiva da sociedade na proteção do meio ambiente.

\footnotetext{
${ }^{54}$ Art. 47. O controle social dos serviços públicos de saneamento básico poderá incluir a participação de órgãos colegiados de caráter consultivo, estaduais, do Distrito Federal e municipais, assegurada a representação:

I - dos titulares dos serviços;

II - de órgãos governamentais relacionados ao setor de saneamento básico;

III - dos prestadores de serviços públicos de saneamento básico;

IV - dos usuários de serviços de saneamento básico;

$V$ - de entidades técnicas, organizações da sociedade civil e de defesa do consumidor relacionadas ao setor de saneamento básico.

55 BRASIL. Lei Federal n.9.985, de julho de 2000. Dispõe sobre a proteção da vegetação nativa; altera as Leis $\mathrm{n}^{0 \mathrm{~S}}$ 6.938, de 31 de agosto de 1981, 9.393, de 19 de dezembro de 1996, e 11.428 , de 22 de dezembro de 2006; revoga as Leis nos 4.771, de 15 de setembro de 1965, e 7.754, de 14 de abril de 1989, e a Medida Provisória no 2.166-67, de 24 de agosto de 2001; e dá outras providências... Disponível em: http://www.planalto.gov.br/ccivil_03/leis/l9985.htm>. Acesso em: 07 jul. 2014.

${ }^{56}$ Art. 1, inciso V - responsabilidade comum da União, Estados, Distrito Federal e Municípios, em colaboração com a sociedade civil, na criação de políticas para a preservação e restauração da vegetação nativa e de suas funções ecológicas e sociais nas áreas urbanas e rurais
} 
PEREIRA, Diego Emmanoel Serafim. O dever de participação na proteção em matéria ambiental na legislação brasileira. Revista Eletrônica Direito e Política, Programa de Pós-Graduação Stricto Sensu em Ciência Jurídica da UNIVALI, Itajaí, v.10, n.1, edição especial de 2015. Disponível em: www.univali.br/direitoepolitica - ISSN 1980-7791.

\section{CONSIDERAÇÕES FINAIS}

A preservação da vida humana e do planeta, diante da ameaça de destruição do meio ambiente é questão abordada por Governos e estudiosos. As mudanças climáticas, extinção de espécies animais e vegetais, a desertificação, são manifestações que mostram o quanto é perigoso não tomar os devidos cuidados na proteção do meio ambiente equilibrado. A ameaça de um colapso no planeta, causada pelos danos ambientais, fizeram com que se quebrassem alguns paradigmas.

Nesse começo de século é vivível a transformação do Estado, de um Estado omisso nas questões de proteção ambiental, para um Estado de Direito Ambiental que busca solucionar a crise ambiental e conscientizar a sociedade e exigir uma cidadania participativa em prol da proteção do meio ambiente. O direito ao meio ambiente ecologicamente equilibrado é um direito de todos, e igualmente cabe a coletividade o deve de proteção.

Uma vez que o bem ambiental pertence à coletiva, a sua proteção deve, também, ser compartilhada por todos os componentes da sociedade, na qual, se exige uma responsabilidade solidária entre o Poder Público, Sociedade Civil e Mercado. A gestão do meio ambiente é encarada como um dever pertencente tanto ao Estado como à coletividade. Por isso, há uma transformação ética nos indivíduos que devem preservar o meio ambiente para as presentes e futuras gerações.

A participação popular na defesa e proteção do meio ambiente equilibrado é encarada como um dever. O dever de participação é visto como um princípio fundamental pela Constituição brasileira. A legislação brasileira possui inúmeras normas que contém a participação popular como uma obrigatoriedade, que vão desde a conscientização da população até a tomada de decisões que busquem garantir a qualidade de vida. Vários instrumentos jurídicos, conforme apresentado neste artigo, permitem e estimulam a participação da sociedade na busca por soluções para encarar a crise ambiental. O dever ético de preservar o meio ambiente é observado em vários mecanismos previstos na legislação brasileira, possibilitando a participação ativa na construção de um Estado de 
PEREIRA, Diego Emmanoel Serafim. O dever de participação na proteção em matéria ambiental na legislação brasileira. Revista Eletrônica Direito e Política, Programa de Pós-Graduação Stricto Sensu em Ciência Jurídica da UNIVALI, Itajaí, v.10, n.1, edição especial de 2015. Disponível em: www.univali.br/direitoepolitica - ISSN 1980-7791.

Direito Ambiental e estimulando a solidariedade na proteção ambiental para as presentes e futuras gerações.

\section{REFERÊNCIAS DAS FONTES CITADAS}

ABREU, Pedro Manoel. Processo e Democracia: o processo jurisdicional como um lócus daa democracia participativa e da cidadania inclusiva no estado democrático de direito. São Paulo: Conceito Editorial, 2011. p.100.

BRASIL. Constituição da República Federativa do Brasil de 5 de outubro de $1988 . \quad$ Disponível em: <http://www.planalto.gov.br/ccivil_03/constituicao/constituicao.htm >. Acesso em: 5 jul. 2014.

BRASIL. Lei no 9.433, de janeiro de 1997. Institui a Política Nacional de Recursos Hídricos, cria o Sistema Nacional de Gerenciamento de Recursos Hídricos, regulamenta o inciso XIX do art. 21 da Constituição Federal, e altera o art. $1^{\circ}$ da Lei no 8.001, de 13 de março de 1990, que modificou a Lei no 7.990, de 28 de dezembro de 1989. Disponível em: http://www.planalto.gov.br/ccivil_03/leis/19433.htm>. Acesso em: 07 jul. 2014.

BRASIL. Lei no 9.985, de janeiro de 1997. Regulamenta 0 art. 225, $\S 1^{\circ}$, incisos I, II, III e VII da Constituição Federal, institui o Sistema Nacional de Unidades de Conservação da Natureza e dá outras providências. Disponível em:<http://www.planalto.gov.br/ccivil_03/leis/l9985.htm>. Acesso em: 07 jul. 2014.

BRASIL. Lei no 10.257, de julho de 2000. Regulamenta os arts. 182 e 183 da Constituição Federal estabelece diretrizes gerais da política urbana e dá outras providências. Disponível em: <http://www.planalto.gov.br/ccivil_03/leis/leis_2001/l10257.htm>. Acesso em: 07 jul. 2014.

BRASIL. Lei no 11.284, de março de 2006. Dispõe sobre a gestão de florestas públicas para a produção sustentável; institui, na estrutura do Ministério do Meio Ambiente, o Serviço Florestal Brasileiro - SFB; cria o Fundo Nacional de Desenvolvimento Florestal - FNDF; altera as Leis $\mathrm{n}^{\mathrm{os}} 10.683$, de 28 de maio de 2003, 5.868, de 12 de dezembro de 1972, 9.605, de 12 de fevereiro de 1998, 4.771 , de 15 de setembro de 1965, 6.938, de 31 de agosto de 1981, e 6.015, de 31 de dezembro de 1973; e dá outras providências. Disponível em:<http://www.planalto.gov.br/ccivil_03/_ato20042006/2006/lei/l11284.htm> Acesso em: 07 jul. 2014

BRASIL. Lei no 11.445, de janeiro de 2007. Estabelece diretrizes nacionais para o saneamento básico; altera as Leis nos 6.766, de 19 de dezembro de 1979, 8.036, de 11 de maio de 1990, 8.666, de 21 de junho de 1993, 8.987, de 13 de 
PEREIRA, Diego Emmanoel Serafim. O dever de participação na proteção em matéria ambiental na legislação brasileira. Revista Eletrônica Direito e Política, Programa de Pós-Graduação Stricto Sensu em Ciência Jurídica da UNIVALI, Itajaí, v.10, n.1, edição especial de 2015. Disponível em: www.univali.br/direitoepolitica - ISSN 1980-7791.

fevereiro de 1995; revoga a Lei $\mathrm{n}^{\circ}$ 6.528, de 11 de maio de 1978; e dá outras providências. Disponível em: < http://www.planalto.gov.br/ccivil_03/_ato20072010/2007/lei/l11445.htm>. Acesso em: 07 jul. 2014.

BRASIL. Lei no 12.187, de dezembro de 2009 Institui a Política Nacional sobre Mudança do Clima - PNMC e dá outras providências.. Disponível em: < http://www.planalto.gov.br/ccivil_03/_ato2007-2010/2009/lei/l12187.htm>. Acesso em: 07 jul. 2014

BRASIL. Lei no 12.305, de agosto de 2010. Institui a Política Nacional de Resíduos Sólidos; altera a Lei no 9.605, de 12 de fevereiro de 1998; e dá outras providências. Disponível em: < http://www.planalto.gov.br/ccivil_03/_ato20072010/2010/lei/l12305.htm>. Acesso em: 07 jul. 2014.

BRASIL. Lei no 9.433, de janeiro de 1997. Institui a Política Nacional de Recursos Hídricos, cria o Sistema Nacional de Gerenciamento de Recursos Hídricos, regulamenta o inciso XIX do art. 21 da Constituição Federal, e altera o art. $1^{\circ}$ da Lei no 8.001, de 13 de março de 1990, que modificou a Lei no 7.990, de 28 de dezembro de 1989. Disponível em: http://www.planalto.gov.br/ccivil_03/leis/I9433.htm>. Acesso em: 07 jul. 2014.

BRASIL. Portaria Ministério do Meio Ambiente no 452, novembro de 2011. Regimento interno do Conselho Nacional do Meio Ambiente. Disponível em: <http://www.mma.gov.br/port/conama/legiabre.cfm?codlegi=656>. Acesso em: 07 jul. 2014.

COSTA NETO, Nicolao Dino de Castro e. Proteção jurídica do meio ambiente. Belo Horizonte, MG: Del Rey, 2003.

FERRER, Gabriel. La construcción del Derecho Ambiental. Disponível em: <http://www.dda.ua.es/documentos/construccion_derecho_ambiental.pdf> Acesso em: 07 jul. 2014

FENSTERSEIFER, Tiago. Direitos fundamentais e proteção ambiental - A dimensão ecológica da dignidade humana no marco jurídico-constitucional do Estado Socioambiental de Direito. Porto Alegre: Livraria do Advogado, 2008

FREITAS, Juarez. Sustentabilidade: direito ao futuro. Belo Horizonte: Editora Fórum. Belo Horizonte, 2011.

LIZARRAGA, J.A. Razquin; ESPINOSA, A. Ruiz de Apoca. Informacion, participación y justiça en materia de medio ambiente. Pamplona: Editora Aranzadi, 2007.

LEITE, José Rubens Morato; AYALA, Patryck de Araújo. Direito ambiental na sociedade de risco. Rio de Janeiro: Forense, 2002.

MANZANO, Jordi Jaria i. El fundamento constitucional de los derechos de participación en materia de medio ambiente y su desarrollo en la ley 27/2006. In: SOLÉ, Antoni Pigrau (Org). Acceso a la información, participación 
PEREIRA, Diego Emmanoel Serafim. O dever de participação na proteção em matéria ambiental na legislação brasileira. Revista Eletrônica Direito e Política, Programa de Pós-Graduação Stricto Sensu em Ciência Jurídica da UNIVALI, Itajaí, v.10, n.1, edição especial de 2015. Disponível em: www.univali.br/direitoepolitica - ISSN 1980-7791.

pública y acceso a la justicia en materia de medio ambiente: diez años del Convenio de Aahus.Barcelona: Ed. Atelier, 2008.

MILARÉ, Édis. Direito do ambiente: a gestão ambiental em foco - doutrina, jurisprudência, glossário. 8. ed. rev. atual. ref. São Paulo: Revista dos tribunais, 2013.

MIRRA, Álvaro Luiz Valery. Participação, processo civil e defesa do meio ambiente. São Pulo: Letras Jurídicas, 2011.

MORIN, Edgar. O método 5: a humanidade da humanidade : a identidade humana.4. ed. Porto Alegre: Sulina, 2007.

Para una política de la civilizacion. Barcelona: Paidos, 2009.

ORGANIZAÇÃO DAS NAÇÕES UNIDAS. Declaração do Rio de Janeiro sobre Meio Ambiente e Desenvolvimento (Declaração do Rio), adotada de 3 a 14 de junho de 1992. Disponível em: < http://www.onu.org.br/rio20/img/2012/01/rio92.pdf >. Acesso em: 05 jul. 2013.

RODRIGUES, Marcelo Abelha. Instituições de Direito Ambiental. Vol. 1. São Paulo: Max Limonad, 2002.

RUSCHEL, Caroline Vieira. Parceria Ambiental: O Dever Fundamental de Proteção Ambiental como Pressuposto para a Concretização do Estado de Direito Ambiental. Curitiba: Juará Editora, 2010.

Submetido em: Setembro/2014

Aprovado em: Outubro/2014 